\title{
Kajian Kedalaman Penggunaan Bajak Singkal Terhadap Perubahan Sifat Fisika-Mekanika, Kapasitas Lapang dan Kebutuhan Bahan Bakar
}

\author{
(Depth study of the use of a pirate against changes in physical-mechanical properties, field \\ capacity and fuel requirements)
}

\author{
Dea Nizatillah ${ }^{1}$, Ramayanti Bulan $^{1}$, Yuswar Yunus ${ }^{1 *}$ \\ ${ }^{1}$ Program Studi Teknik Pertanian, Fakultas Pertanian, Universitas Syiah Kuala \\ *Corresponding author: yuswaryunus@unsyiah.ac.id
}

\begin{abstract}
Abstrak: Pengolahan tanah dengan traktor menyebabkan terjadinya pemadatan tanah yang pada akhirnya mempengaruhi produktivitas tanaman. Tujuan dari penelitian ini adalah untuk mengetahui bagaimana pengaruh kedalaman penggunaan bajak singkal terhadap sifat fisika-mekanika tanah, kapasitas lapang dan konsumsi bahan bakar. Metode yang digunakan pada penelitian ini adalah metode eksperimen dengan menggunakan rancangan acak kelompok (RAK) non faktorial. Hasil penelitian menunjukkan bahwa kedalaman penggunaan singkal dan kecepatan kerja berpengaruh nyata terhadap bobot isi, porositas, $\mathrm{pF} 2.0$, permeabilitas dan stabilitas agregat, akan tetapi perlakuan kedalaman penggunaan singkal tidak berpengaruh nyata terhadap pF 2,54 dan tahanan penetrasi tanah. Kapasitas lapang memberi pengaruh terhadap konsumsi bahan bakar. Efisiensi lapang terbaik terdapat pada pengolahan tanah dengan kedalaman pembajakan $20 \mathrm{~cm}$, yaitu $81,33 \%$. Konsumsi bahan bakar paling irit untuk pembajakan tanah adalah menggunakan kedalaman pembajakan tanah $20 \mathrm{~cm}$, yaitu sebesar 2,83 L/Jam. Terdapat hubungan antara kedalaman penggunaan bajak singkal dengan perubahan sifat fisika-mekanika tanah dan kapasitas lapang serta kebutuhan bahan bakar. Bobot isi tanah, kadar air pada $\mathrm{pF} 2.0$ dan $\mathrm{pF}$ 2,54 pada setiap kedalaman pembajakan tanah memiliki hubungan yang sangat lemah terhadap kebutuhan bahan bakar. Porositas total, permeabilitas, stabilitas agregat dan ketahanan penetrasi tanah pada setiap kedalaman pembajakan tanah memiliki hubungan yang sedang terhadap kebutuhan bahan bakar. Sedangkan perlakuan kedalaman pembajakan tanah dengan kapasitas lapang memiliki hubungan yang sangat kuat terhadap konsumsi bahan bakar.
\end{abstract}

Kata Kunci : Kedalaman pembajakan, sifat fisika-mekanika tanah, kapasitas lapang, konsumsi bahan bakar

\begin{abstract}
Soil plowing with tractors causes soil compaction which ultimately affects crop productivity. The purpose of this study was to find out how the plowing depth of use of pirate plows on soil physical-mechanical properties, field capacity and fuel consumption. The method used in this study is an experimental method using a non factorial randomized block design (RBD). The results showed that the depth of use of the screen and work speed significantly affected the weight of the content, porosity, $\mathrm{pF} 2.0$, permeability and aggregate stability, but the treatment of the depth of use of the cassava had no significant effect on pF 2.54 and soil penetration resistance. Field capacity influences fuel consumption. The best field efficiency is found in tillage with a depth of $20 \mathrm{~cm}$ piracy, which is $81.33 \%$. The most economical fuel consumption for land hijacking is using a $20 \mathrm{~cm}$ soil plowing depth, which is $2.83 \mathrm{~L} /$ Hour. There is a relationship between the depth of use of a plow with changes in physical-mechanical properties of the soil and field capacity and fuel requirements. The weight of the soil, the water content at pF 2.0 and pF 2.54 at each depth of land piracy has a very weak relationship with fuel requirements. Total porosity, permeability, aggregate stability and soil penetration resistance at every depth of soil piracy have a moderate relationship to fuel requirements. While the treatment of the depth of land piracy with field capacity has a very strong relationship to fuel consumption.
\end{abstract}

Keywords :Piracy depth, soil physical-mechanical properties, field capacity, fuel consumption 


\section{PENDAHULUAN}

Tanah sebagai sumber daya di bidang pertanian memiliki fungsi atau manfaat yang besar bagi kehidupan manusia dan makhluk hidup lainnya. Kualitas sifat fisik dan biologis tanah masih bisa diperbaiki dengan perlakuan-perlakuan yang dapat meningkatkan kesuburan tanah, karena sifat tanah dinamis serta perlu teknik pengolahan tanah yang benar. Di dalam usaha pertanian, pengolahan tanah dilakukan dengan tujuan untukmenciptakan kondisi fisik, khemis dan biologis tanah yang lebih baik sampai kedalaman tertentu untuk pertumbuhan tanaman.

Penggunaan traktor untuk pengolahan tanah merupakan salah satu upaya penggemburan tanah menjadi suatu media siap tanam yang dapat dicapai melalui proses pembajakan (Kramadibrata, 2000). Peralatan yang digunakan traktor dalam mengolah tanah sangat beragam. Bajak singkal merupakan salah satu implemen traktor yang digunakan untuk melakukan pengolahan tanah.

Menurut Yunus (2013) pengolahan tanah yang dipengaruhi oleh lintasan pembajakan dan kecepatan kerja traktor, mempengaruhi kedalaman pembajakan dan kecepatan kerja, juga berpengaruh terhadap kapasitas lapang dan kebutuhan bahan bakar. Daywin dkk (2008) menyatakan bahwa ada dua macam kapasitas pengolahan tanah, yaitu kapasitas lapang teoritis dan kapasitas lapang efektif. Kapasitas lapang teoritis adalah kemampuan kerja suatu alat di dalam suatu bidang tanah, jika mesin berjalan maju sepenuh waktunya (100\%) dan alat tersebut bekerja dalam lebar maksimum (100\%). Kapasitas lapang efektif adalah ratarata dari kemampuan kerja alat di lapangan untuk menyelesaikan suatu bidang tanah. Kapasitas lapang dapat dinyatakan dalam acre per jam atau hektar per jam.

\section{BAHAN DAN METODE}

\section{Tempat dan Waktu Penelitian}

Penelitian dilakukan di Balai Pengkajian Teknologi Pertanian (BPTP) Banda Aceh. Tanah pada lahan penelitian ini termasuk dalam ordo Entisol. Analisis tanah dilakukan di Laboratorium Fisika Tanah dan Lingkungan Fakultas Pertanian Universitas Syiah Kuala, Banda Aceh. Penelitian dilaksanakan selama \pm 2 bulan terhitung sejak September 2017 sampai dengan Februari 2018.

\section{Alat dan Bahan}

Peralatan yang digunakan di lapangan untuk penelitian ini terdiri dari satu unit traktor roda empat dengan implemen bajak singkal. Sedangkan alat-alat untuk pengambilan sampel tanah adalah penetrometer, stopwatch ring sample, parang, cangkul, sekop, meteran serta alat pendukung lainnya. Bahan yang digunakan dalam penelitian ini adalah lahan olahan dan bahan bakar minyak.

\section{Metode Penelitian}

Penelitian ini menggunakan metode eksperimen dengan rancangan acak kelompok (RAK) non faktorial, menggunakan satu faktor. Faktor yang dicobakan adalah kedalaman penggunaan bajak singkal (T). Pengolahan data dilakukan dengan menggunakan Microsoft Excel. 


\section{Rancangan Perlakuan}

Rancangan perlakuan yang digunakan dalam penelitian ini adalah variasi

kedalaman peggunaan bajak singkal yang terdiri dari dua taraf yaitu:

1. Kedalaman pembajakan tanah 0-20 cm (T1)

2. Kedalaman pembajakan tanah 0-30 cm (T2)

Tabel 1. Kombinasi Perlakuan Kedalaman Pembajakan Tanah dan Kapasitas Lapang

\begin{tabular}{cccccccc}
\hline \multirow{2}{*}{ No } & Kedalaman Pembajakan Tanah & \multicolumn{7}{c}{ Ulangan $(\mathrm{U})$} \\
\cline { 2 - 7 } & $(\mathrm{T})$ & $\mathrm{U}_{1}$ & $\mathrm{U}_{2}$ & $\mathrm{U}_{3}$ & $\mathrm{U}_{4}$ & $\mathrm{U}_{5}$ & $\mathrm{U}_{6}$ \\
\hline 1 & $\mathrm{~T}_{1}$ & $\mathrm{~T}_{1} \mathrm{U}_{1}$ & $\mathrm{~T}_{1} \mathrm{U}_{2}$ & $\mathrm{~T}_{1} \mathrm{U}_{3}$ & $\mathrm{~T}_{1} \mathrm{U}_{4}$ & $\mathrm{~T}_{1} \mathrm{U}_{5}$ & $\mathrm{~T}_{1} \mathrm{U}_{6}$ \\
2 & $\mathrm{~T}_{2}$ & $\mathrm{~T}_{2} \mathrm{U}_{1}$ & $\mathrm{~T}_{2} \mathrm{U}_{2}$ & $\mathrm{~T}_{2} \mathrm{U}_{3}$ & $\mathrm{~T}_{2} \mathrm{U}_{4}$ & $\mathrm{~T}_{2} \mathrm{U}_{5}$ & $\mathrm{~T}_{2} \mathrm{U}_{6}$ \\
\hline
\end{tabular}

\section{Rancangan Percobaan}

Penelitian ini menggunakan Rancangan Acak Kelompok (RAK) non faktorial. Total kombinasi perlakuan adalah 2 plot percobaan, diulang sebanyak 6 kali, sehingga seluruhnya berjumlah 12 plot percobaan.

\section{Rancangan Analisis}

Aspek analisis tanah sebelum dan setelah perlakuan pembajakan tanah terdiri atas analisis sifat fisika dan mekanika tanah. Sifat fisika tanah terdiri atas bobot isi, porositas total, distribusi pori, permeabilitas serta indeks stabilitas agregrat. Sifat mekanika tanah yang di uji yaitu tahanan penetrasi tanah.

\section{Prosedur Percobaan}

Prosedur percobaan terdiri dari:

1. Persiapan lahan

2. Pengambilan sampel tanah awal

3. Pengujian pengolahan tanah

4. Pengambilan sampel tanah terganggu

\section{Analisa Data}

Pengujian hipotesa dilakukan dengan mengolah data yang diperoleh secara parametrik. Untuk mengetahui pengaruh faktor perlakuan terhadap sifat fisika-mekanika tanah diuji dengan sidik ragam (ANOVA) atau uji Fisher (F) pada probabilitas atau tingkat peluang 0,05 (Gomez dan Gomes, 1995). Sedangkan untuk melihat perbedaan rata-rata respons perlakuan, jika perlakuan berpengaruh nyata akan dilanjutkan dengan uji Beda Nyata Terkecil (BNT) pada $\alpha 0,05$. 


\section{HASIL DAN PEMBAHASAN}

\section{Analisis Sifat Fisika dan Mekanika Tanah Sebelum Percobaan}

Lahan tempat penelitian ini berupa lahan kering dalam keadaan berumput dan bertopografi datar, memiliki tekstur tanah dengan persentase pasir sebesar 22,25\%, persentase debu sebesar 34,65\% dan persentase liat sebesar 42,80 \%. Berdasarkan diagram segitiga tekstur menunjukkan bahwa tanah tersebut termasuk kedalam tekstur tanah liat. Hasil analisis sifat fisika dan mekanika tanah sebelum dilakukan pembajakan dengan traktor roda empat dapat dilihat pada Tabel 2.

Tabel 2. Hasil analisis sifat fisika dan mekanika tanah sebelum perlakuan

\begin{tabular}{|c|c|c|c|c|c|c|}
\hline \multirow{2}{*}{$\begin{array}{l}\text { Bobot Isi } \\
\left(\mathrm{gr} / \mathrm{cm}^{3}\right)\end{array}$} & \multirow{2}{*}{$\begin{array}{l}\text { Porositas } \\
\quad(\%)\end{array}$} & \multirow{2}{*}{$\begin{array}{l}\text { Permeabilitas } \\
(\mathrm{cm} / \mathrm{jam})\end{array}$} & \multicolumn{2}{|c|}{$\underset{(\%)}{\text { Kurva Tegangan }}$ Air $(\mathrm{pF})$} & \multirow{2}{*}{$\begin{array}{c}\text { Stabilitas } \\
\text { Agregrat } \\
(\%)\end{array}$} & \multirow{2}{*}{$\begin{array}{c}\text { Tahanan } \\
\text { Penetrasi } \\
\text { Tanah } \\
\left(\mathrm{kgf} / \mathrm{cm}^{2}\right)\end{array}$} \\
\hline & & & $\mathrm{pF} \quad 2,0$ & $\mathrm{pF} 2,54$ & & \\
\hline 1,42 & 38,94 & 0,76 & 34,38 & 27,38 & 63,48 & 19 \\
\hline
\end{tabular}

Sumber: Hasil Analisis Laboratorium Fisika Tanah dan Lingkungan Fakultas Pertanian Unsyiah, 2019

Tabel 2 menunjukkan bahwa bobot isi tanah sebelum pengolahan adalah 1,42 $\mathrm{gr} / \mathrm{cm}^{3}$, porositas total sebesar $38,94 \%$, permeabilitas sebesar $0,76 \mathrm{~cm} / \mathrm{jam}$, kurva tegangan air $(\mathrm{pF}$ ) 2,00 sebesar 34,38\%, pF 2,54 sebesar 27,38\% , stabilitas agregat sebesar 63,48\% dan tahanan penetrasi tanah sebesar $19\left(\mathrm{kgf} / \mathrm{cm}^{2}\right)$.

\section{Pengaruh Kedalaman Pembajakan Tanah Terhadap Sifat Fisika-Mekanika Tanah}

Setelah pengolahan tanah dikerjakan maka dilakukan pengambilan sample tanah untuk menganalisis sifat fisika-mekanika tanah. Hasil analisis sifat fisika-mekanika tanah setelah dilakukan pembajakan dengan traktor roda empat dapat dilihat pada Tabel 3.

Tabel 3. Hasil Analisis Sifat Fisika-Mekanika Tanah Setelah Perlakuan

\begin{tabular}{|c|c|c|c|c|c|c|c|}
\hline \multirow{2}{*}{ Perlakuan } & \multirow{2}{*}{$\begin{array}{l}\text { Bobot Isi } \\
\left(\mathrm{g} / \mathrm{cm}^{3}\right)\end{array}$} & \multirow{2}{*}{$\begin{array}{c}\text { Porositas } \\
(\%)\end{array}$} & \multirow{2}{*}{$\begin{array}{l}\text { Permeabilitas } \\
(\mathrm{cm} / \mathrm{jam})\end{array}$} & \multicolumn{2}{|c|}{$\begin{array}{c}\text { Kurva Tegangan Air }(\mathrm{pF}) \\
(\%)\end{array}$} & \multirow{2}{*}{$\begin{array}{c}\text { Indeks } \\
\text { Stabilitas } \\
\text { Agregat (\%) }\end{array}$} & \multirow{2}{*}{$\begin{array}{c}\text { Tahanan } \\
\text { Penetras } \\
\text { Tanah } \\
\left(\mathrm{kgf} / \mathrm{cm}^{2}\right.\end{array}$} \\
\hline & & & & $\mathrm{pF} 2,0$ & $\mathrm{pF} 2,54$ & & \\
\hline $\mathrm{T} 1$ & 1,41 & 40,40 & 0,34 & 33,50 & 27,74 & 61,12 & 21,86 \\
\hline $\mathrm{T} 2$ & 1,40 & 42,05 & 0,39 & 34,56 & 27,36 & 62,18 & 22,33 \\
\hline BNT & 0,003 & 29,57 & 0,035 & 12,25 & 1,589 & 12,14 & 2,409 \\
\hline
\end{tabular}

\section{a. Bobot Isi Tanah (Bulk Density)}

Bobot isi tanah merupakan sifat fisik tanah yang dapat menunjukkan kegemburan atau tingkat kepadatan tanah. Bobot isi tanah sebelum dilakukan perlakuan pembajakan tanah adalah $1,42 \mathrm{~g} / \mathrm{cm}^{3}$, sementara bobot isi tanah setelah dilakukan pembajakan tanah berkisar antara 1,39-1,42 $\mathrm{g} / \mathrm{cm}^{3}$. Hasil analisis sidik ragam menunjukkan bahwa kedalaman pembajakan tanah berpengaruh sangat nyata terhadap bobot isi tanah.

Tabel 3 menunjukkan bahwa nilai bobot isi tertinggi terdapat pada kedalaman pembajakan tanah $20 \mathrm{~cm}$ sebesar $1,41 \mathrm{~g} / \mathrm{cm}^{3}$, sedangkan nilai terendah terdapat pada kedalaman pembajakan tanah $30 \mathrm{~cm}$ sebesar $1,40 \mathrm{~g} / \mathrm{cm}^{3}$. Hal ini dikarenakan pembajakan tanah dapat menyebabkan ruang pori dalam tanah lebih besar sehingga terjadi penurunan bobot isi tanah. Wahyuni (2014) menyatakan bahwa bobot isi tanah cenderung menurun 
seiring dengan besarnya kedalaman pengolahan tanah yang dilakukan. Dalam penelitiannya menyimpulkan bahwa semakin kecil kedalaman pengolahan tanah maka nilai bobot isi tanah semakin tinggi dan sebaliknya semakin besar perlakuan pengolahan tanah maka nilai bobot isi tanah semakin menurun.

\section{b. Porositas}

Porositas total merupakan volume dari seluruh pori-pori dalam suatu volume tanah utuh, dinyatakan dalam persen. Porositas total tanah sebelum dilakukan pembajakan tanah adalah sebesar 38,94\%, sementara porositas total setelah dilakukan pembajakan tanah berkisar antara 39,37-42,17 \%. Analisis sidik ragam menunjukkan bahwa porositas tanah berpengaruh nyata terhadap kedalaman pembajakan tanah.

Tabel 3 menunjukkan bahwa nilai porositas total tertinggi terdapat pada kedalaman pembajakan tanah $30 \mathrm{~cm}$ sebesar 42,05\%. Porositas tanah terendah terdapat pada kedalaman pembajakan tanah $20 \mathrm{~cm}$ sebesar 40,40\%. Hal ini menunjukkan bahwa nilai porositas tanah semakin tinggi seiring dengan besarnya kedalaman pembajakan tanah yang dilakukan, karena dengan adanya pengolahan tanah maka tanah akan menjadi lebih gembur sehingga ruang pori didalam tanah menjadi lebih besar. Alhadi (2012) dalam penelitiannya mengatakan bahwa porositas tanah akibat bajak lebih tinggi yang berbedadengan tanpa bajak, karena dengan menggunakan bajak tanah akan menjadi gembur (struktur tanah hancur) dan porositas tanah menjadi lebih baik sehingga kemampuan tanah dalam meloloskan air lebih tinggi.

\section{c. Kadar Air tanah}

Kadar air tanah merupakan tingkat kelembaban tanah atau kandungan air tanah yang dinyatakan dalam persen volum, yaitu persentase volume air terhadap volume tanah. Besarnya tegangan air $(\mathrm{pF})$ menunjukkan besarnya tenaga yang diperlukan untuk menahan air di dalam tanah.

Kadar air pada pF 2,0 sebelum dilakukan pembajakan tanah adalah 34,38 \%, sedangkan hasil setelah dilakukan pengolahan tanah berkisar antara 32,04 \% - 35,42\%. Analisis sidik ragam menunjukkan bahwa kedalaman pembajakan tanah berpengaruh nyata terhadap kadar air pada $\mathrm{pF} 2,0$.

Tabel 3 menunjukkan bahwa nilai kadar air pada $\mathrm{pF}$ 2,0 terendah terdapat pada kedalaman pembajakan tanah $20 \mathrm{~cm}$ yaitu 33,50\%, sedangkan nilai kadar air pada pF 2,0 tertinggi terdapat pada kedalaman pembajakan tanah $30 \mathrm{~cm}$ yaitu $34,56 \%$. Nilai pF 2,0 mengalami peningkatan seiring dengan semakin besarnya kedalaman pembajakan tanah yang dilakukan. Wahyuni (2014) dalam penelitiannya mengatakan bahwa semakin besar pembajakan tanah yang dilakukan maka dapat meningkatkan ruang pori tanah dengan demikian dapat mempercepat masuknya air ke dalam tanah sehingga memperbesar persentase pori-pori tanah pada lahan penelitian tersebut.

Kadar air pada pF 2,54 sebelum dilakukan pembajakan tanah adalah 27,38\%, sedangkan hasil setelah dilakukan pembajakan tanah berkisar antara 25,39 \% - 28,51\%. Hasil analisis sidik ragam menunjukkan bahwa perlakuan kedalaman pembajakan tanah tidak berpengaruh nyata terhadap kadar air pada $\mathrm{pF} 2,54$.

Tabel 3 menunjukkan bahwa nilai kadar air pada $\mathrm{pF}$ 2,54 terendah terdapat pada kedalaman pembajakan tanah $30 \mathrm{~cm}$ yaitu $27,36 \%$, sedangkan nilai kadar air pada $\mathrm{pF} 2,54$ tertinggi terdapat pada kedalaman pembajakan tanah $20 \mathrm{~cm}$ yaitu 27,74\%. Nilai kadar air pada $\mathrm{pF}$ 2,54 mengalami penurunan seiring dengan semakin tingginya kedalaman pembajakan tanah. Adanya penurunan ini dapat terjadi akibat dari perlakuan pembajakan 
tanah yang menyebabkan pemadatan tanah oleh gaya berat dari traktor sehingga menyebabkan rusaknya agregat tanah dan struktur tanah mengalami perubahan. Kepner et al (1982) dalam Aswinsyah (2015) menambahkan bahwa pengolahan tanah dengan bajakan dapat menyebabkan agregat tanah menjadi lebih kecil dengan tingkat stabilitas agregat yang sangat rendah, konsekuensinya pori-pori tanah lebih mudah mengalami penyumbatan akibat disperse fraksi yang berukuran halus sehingga persentase pori-pori tanah menjadi rendah.

\section{d. Permeabilitas}

Permeabilitas merupakan karakteristik sifat fisik tanah yang menunjukkan laju pergerakan air didalam tanah. Permeabilitas tanah sebelum dilakukan perlakuan pembajakan tanah adalah sebesar $0,76 \mathrm{~cm} / \mathrm{jam}$. Permeabilitas tanah setelah dilakukan pembajakan tanah berkisar antara $0,30 \mathrm{~cm} / \mathrm{jam}-0,44 \mathrm{~cm} / \mathrm{jam}$. Analisis sidik ragam menunjukkan bahwa permeabilitas berpengaruh nyata terhadap terhadap kedalaman pembajakan tanah.

Tabel 3 menunjukkan bahwa nilai permeabilitas tertinggi terdapat pada pembajakan tanah $30 \mathrm{~cm}$ yaitu $0,39 \mathrm{~cm} / \mathrm{jam}$. Permeabilitas tanah terendah terdapat kedalaman pembajakan tanah $20 \mathrm{~cm}$ yaitu sebesar $0,34 \mathrm{~cm} / \mathrm{jam}$. Terjadinya kenaikan nilai permeabilitas, erat kaitannya dengan perlakuan kedalaman pembajakan tanah. Salah satu faktor yang mempengaruhi nilai permeabilitas adalah struktur tanah. Alhadi dkk (2012) dalam penelitiannya mengatakan bahwa dengan dilakukan pengolahaan tanah $30 \mathrm{~cm}$ maka dapat menciptakan ruang pori yang baik untuk pergerakan air didalam tanah sehingga permeabilitas tanah akan meningkat.

\section{e. Stabilitas Agregat}

Stabilitas agregat merupakan ketahanan tanah terhadap daya yang dapat menimbulkan penghancuran agregrat tanah. Nilai stabilitas agregat sebelum dilakukan perlakuan pembajakan tanah adalah sebesar $63,48 \%$, sementara stabilitas agregat setelah dilakukan pembajakan tanah berkisar antara 60,15\% - 62,68 \%. Analisis sidik ragam menunjukkaan bahwa kedalaman pembajakan tanah berpengaruh nyata terhadap stabilitas agregat tanah.

Tabel 3 menunjukkan bahwa stabilitas agregat terendah terdapat pada kedalaman pembajakan tanah $20 \mathrm{~cm}$, yaitu sebesar $61,12 \%$. Stabilitas agregat tertinggi terdapat pada kedalaman pembajakan tanah $30 \mathrm{~cm}$, yaitu sebesar $62,18 \%$. Hasil penelitian menunjukkan bahwa indeks stabilitas agregat meningkat seiring dengan semakin besarnya kedalaman pembajakan tanah yang dilakukan. Menurut Baver et al (1976) dalam Yunus (2013) semakin banyak agregat tanah yang terbentuk dan mantap, semakin tahan tanah tersebut dengan erosi. Suatu tanah yang mempunyai kemantapan agregat besar akan mempunyai kapasitas infiltrasi minimum lebih besar dari pada tanah dengan kemantapan agregatnya kecil.

\section{e. Tahanan Penetrasi Tanah}

Tahanan penetrasi tanah merupakan ketahanan tanah terhadap tembusan suatu alat. Tahanan penetrasi tanah sebelum dilakukan pembajakan tanah adalah sebesar 19,00 $\mathrm{kgf} / \mathrm{cm} 2$, sementara tahanan penetrasi tanah setelah dilakukan pembajakan tanah berkisar antara $20,00 \mathrm{kgf} / \mathrm{cm}^{2}-24,25 \mathrm{kgf} / \mathrm{cm}^{2}$. Analisis sidik ragam menunjukkaan bahwa perlakuan kedalaman pembajakan tanah tidak berpengaruh nyata terhadap tahanan penetrasi tanah.

Berdasarkan Tabel 3 dapat dilihat bahwa nilai tahanan penetrasi tanah tertinggi terdapat pada kedalaman pembajakan tanah $30 \mathrm{~cm}$ yaitu $22,61 \mathrm{kgf} / \mathrm{cm}^{2}$, sedangkan nilai tahanan penetrasi tanah terendah terdapat pada kedalaman $20 \mathrm{~cm}$ yaitu $21,75 \mathrm{kgf} / \mathrm{cm}^{2}$. Kedalaman pembajakan dengan traktor dapat menyebabkan terjadinya pemadatan tanah. 
Akibat dari pemadatan tanah tersebut tahanan penetrasi tanah semakin meningkat. Yunus (2001) menyatakan bahwa semakin rendah tingkat kadar air dan tinggi kedalaman tanah, maka semakin besar nilai tahanan penetrasinya. Hal tersebut sesuai dengan pendapat Mardinata dan Zulkifli (2014) dalam penelitiannya mengatakan bahwa tahanan penetrasi tanah akan semakin besar jika kedalaman olah tanah semakin dalam.

\section{Kapasitas Lapang dan Kebutuhan Bahan Bakar}

Kapasitas lapang menunjukkan seberapa besar luasan tanah yang dapat diolah oleh traktor per satuan waktu tertentu. Ini berkaitan dengan lebarnya daerah pembajakan oleh traktor dan kecepatan traktor tersebut pada saat melakukan pengolahaan tanah. Kebutuhan bahan bakar memiliki hubungan yang kuat dengan kecepatan traktor dan luas areal yang dilintasi traktor. Hasil pengukuran kapasitas lapang dan kebutuhan bahan bakar setelah dilakukan pembajakan tanah dapat dilihat pada Tabel 4.

Tabel 4. Hasil analisis kapasitas lapang dan kebutuhan bahan bakar (ha/jam)

\begin{tabular}{ccccccc}
\hline $\begin{array}{c}\text { Kedalaman } \\
(\mathrm{cm})\end{array}$ & $\begin{array}{c}\text { Kecepatan } \\
(\mathrm{km} / \mathrm{jam})\end{array}$ & $\begin{array}{c}\text { Waktu } \\
\text { Tempuh } \\
(\text { jam })\end{array}$ & $\begin{array}{c}\text { Kapasitas } \\
\text { Lapang } \\
\text { Teoritis } \\
(\text { ha/jam) }\end{array}$ & $\begin{array}{c}\text { Kapasitas } \\
\text { Lapang } \\
\text { Efektif } \\
\text { (ha/jam) }\end{array}$ & $\begin{array}{c}\text { Efisiensi } \\
(\%)\end{array}$ & $\begin{array}{c}\text { Kebutuhan } \\
\text { Bahan Bakar } \\
(\text { liter/jam) }\end{array}$ \\
\hline 20 & 5 & 0,053 & 0,15 & 0,122 & 81,33 & 2,83 \\
30 & 5 & 0,068 & 0,15 & 0,095 & 63,33 & 3,09 \\
\hline
\end{tabular}

Tabel 4 menunjukkan bahwa kapasitas lapang teoritis yang diperoleh pada setiap kedalaman pembajakan tanah adalah sama, yaitu $0,15 \mathrm{ha} / \mathrm{jam}$. Hal ini dikarenakan lebar alat saat pembajakan tanah pada kedalaman $20 \mathrm{~cm}$ dan $30 \mathrm{~cm}$ sebesar $0,3 \mathrm{~m}$ dan kecepatan kerja traktor yang dilakukan pada setiap kedalaman pembajakan tanah adalah konstan $5 \mathrm{~km} / \mathrm{jam}$. Persamaan kecepatan dan lebar alat tersebut menyebabkan nilai kapasitas efektif sama besarnya pada setiap kedalaman pembajakan tanah.

Dari Tabel di atas juga terlihat bahwa kapasitas lapang efektif tertinggi terdapat pada kedalaman $20 \mathrm{~cm}$ sebesar $0,122 \mathrm{ha} / \mathrm{jam}$ dan kapasitas terendah terdapat pada kedalaman 30 $\mathrm{cm}$ sebesar 0,095 ha/jam. Pada penelitian ini kapasitas lapang efektif semakin tinggi saat kedalaman semakin kecil. Hal ini dipengaruhi oleh lama waktu pengolahan dan luas lahan yang terolah. Lama waktu pembajakan tanah pada kedalaman $20 \mathrm{~cm}$ sebesar 0,053 jam dalam luasan $64,5 \mathrm{~m}^{2}$, sedangkan lama waktu pembajakan tanah pada kedalaman $30 \mathrm{~cm}$ sebesar 0,068 jam dalam luasan $64,5 \mathrm{~m}^{2}$. Lama waktu pembajakan tanah pada kedalaman 20 $\mathrm{cm}$ lebih cepat dibandingkan dengan pembajakan tanah pada kedalaman $20 \mathrm{~cm}$. Pengolahan tanah yang baik adalah pengolahan tanah yang dapat diselesaikan dalam waktu yang cepat, artinya pengolahan tanah pada kedalaman pembajakan $20 \mathrm{~cm}$ lebih baik dibandingkan dengan kedalaman $30 \mathrm{~cm}$.

Efisiensi merupakan perbandingan antara kapasitas lapang teoritis dengan kapasitas lapang efektif. Hasil yang didapat dari perhitungan efisiensi lapang untuk kedalaman pembajakan tanah $20 \mathrm{~cm}$ sebesar $81,33 \%$ sedangkan efisiensi lapang untuk pembajakan tanah pada kedalaman $30 \mathrm{~cm}$ sebesar $63,33 \%$. Hasil perhitungan perbandingan efisiensi pada kedalaman pembajakan tanah $20 \mathrm{~cm}$ lebih besar dibandingkan dengan pembajakan tanah pada kedalaman $30 \mathrm{~cm}$, artinya efisiensi lapang pada kedalaman pembajakan tanah 20 $\mathrm{cm}$ lebih baik dibandingkan dengan kedalaman pembajakan $30 \mathrm{~cm}$. Sebagaimana pendapat Yuswar (2004), semakin luas tanah yang diselesaikan dalam waktu yang semakin singkat maka dikatakan bahwa pekerjaan mengolah tanah tersebut mempunyai efisiensi tanah yang tinggi. 
Tabel 4 menunjukkan bahwa kebutuhan bahan bakar pada kedalaman pembajakan tanah $20 \mathrm{~cm}$ sebesar 2,83 liter/jam dan kebutuhan bahan bakar pada pembajakan tanah dengan kedalaman $30 \mathrm{~cm}$ sebesar 3,09 liter/jam. Artinya, kebutuhan bahan bakar paling rendah untuk pembajakan tanah adalah menggunakan kedalaman pembajakan tanah $20 \mathrm{~cm}$.

Pada penelitian ini terlihat bahwa kebutuhan bahan bakar semakin besar saat kedalaman pembajakan tanah semakin dalam. Hal ini dipengaruhi oleh lamanya waktu pengolahan lahan. Waktu kerja traktor saat pengolahan lahan pada kedalaman pembajakan tanah $20 \mathrm{~cm}$ lebih cepat dibandingkan waktu kerja traktor saat pengolahan lahan pada kedalaman $30 \mathrm{~cm}$ sehingga kebutuhan bahan bakar terendah dalam pengolahan tanah adalah pembajakan tanah dengan kedalaman $20 \mathrm{~cm}$.

Mardinata dan Zulkifli (2014) dalam penelitiannya mengatakan bahwa semakin dalam pembajakan maka akan semakin lambat traktor berjalan karena tenaga traktor yang diperlukan akan semakin besar. Akibatnya semakin besar pula tenaga yang dibutuhkan untuk menggerakkan traktor. Tenaga traktor dihasilkan dari perputaran torak dalam silinder, maka akan semakin banyak menghabiskan bahan bakar. 


\section{KESIMPULAN DAN SARAN}

\section{Kesimpulan}

Berdasarkan hasil penelitian kajian kedalaman penggunaan bajak singkal terhadap perubahan sifat Fisika-Mekanika, kapasitas lapang dan kebutuhan bahan bakar, dapat diambil beberapa kesimpulan sebagai berikut:

1. Kedalaman penggunaan singkal dan kecepatan kerja berpengaruh nyata terhadap bobot isi, porositas, $\mathrm{pF}$ 2.0, permeabilitas dan stabilitas agregat, akan tetapi perlakuan kedalaman penggunaan singkal tidak berpengaruh nyata terhadap $\mathrm{pF}$ 2,54 dan tahanan penetrasi tanah.

2. Kapasitas lapang memberi pengaruh terhadap konsumsi bahan bakar. Kapasitas lapang teoritis pada kedalaman pembajakan tanah $20 \mathrm{~cm}$ sama dengan kedalaman pembajakan tanah $30 \mathrm{~cm}$, yaitu sebesar $0,15 \mathrm{Ha} / \mathrm{jam}$. Kapasitas lapang efektif tertinggi terdapat pada kedalaman pembajakan $20 \mathrm{~cm}$ sebesar $0,127 \mathrm{Ha} / \mathrm{jam}$ dan kapasitas terendah terdapat pada kedalaman $30 \mathrm{~cm}$ sebesar 0,095 Ha/Jam. Efisiensi lapang terbaik terdapat pada pengolahan tanah dengan kedalaman pembajakan $20 \mathrm{~cm}$, yaitu $81,33 \%$. Konsumsi bahan bakar paling irit untuk pembajakan tanah adalah menggunakan kedalaman pembajakan tanah $20 \mathrm{~cm}$, yaitu sebesar $2,83 \mathrm{~L} / \mathrm{Jam}$.

3. Terdapat hubungan antara kedalaman penggunaan bajak singkal dengan perubahan sifat fisika-mekanika tanah dan kapasitas lapang serta kebutuhan bahan bakar. Bobot isi tanah, kadar air pada pF 2.0 dan $\mathrm{pF} 2,54$ pada setiap kedalaman pembajakan tanah memiliki hubungan yang sangat lemah terhadap kebutuhan bahan bakar. Porositas total, permeabilitas, stabilitas agregat dan ketahanan penetrasi tanah pada setiap kedalaman pembajakan tanah memiliki hubungan yang sedang terhadap kebutuhan bahan bakar. Sedangkan perlakuan kedalaman pembajakan tanah dengan kapasitas lapang memiliki hubungan yang sangat kuat terhadap konsumsi bahan bakar.

\section{Saran} selanjutnya:

Setelah melakukan penelitian ini, berikut adalah beberapa saran untuk penelitian

1. Perlu dilakukan penelitian lanjutan dengan membandingkan pengaruh kedalaman pembajakan tanah pada berbagai kecepatan kerja traktor terhadap sifat fisika-mekanika tanah, kapasitas lapang dan konsumsi bahan bakar pada ordo tanah lainnya.

2. Untuk memperoleh hasil yang lebih baik, disarankan untuk melakukan penelitian dengan menggunakan jenis bajak lainnya dan pada ordo tanah yang berbeda. 


\section{DAFTAR PUSTAKA}

Al-Hadi, B., Yunus, Y., M. Idkham. 2012. Analisis Sifat Fisika Tanah Akibat Lintasan Traktir Roda Empat. Jurnal Manajemen Sumber Daya Lahan, Vol. 1, No. 1, Juni 2012. Universitas Syiah Kuala, Banda Aceh.

Aswinsyah, A. 2015. Pengaruh Pengolahan Tanah dengan Menggunakan Bajak Piring dan Pemupukan Kalium Terhadap Pertumbuhan serta Produksi Tanaman Jagung (Zea mays L.). Skripsi. Fakultas Pertanian Unsyiah. Darussalam, Banda Aceh.

Daywin, F. J., R. G. Sitompul, I. Hidayat. 2008. Mesin-Mesin Budidaya Pertanian di Lahan Kering. Penerbit Graha Ilmu, Yogyakarta.

Fahrunnisa, R. 2016. Pengaruh Lintasan Traktor dengan Menggunakan Bajak Singkal Terhadap Perubahan Sifat Fisika-Mekanika Tanah dan Pertumbuhan serta Produksi Tanaman Kacang Hijau (Vigna radiata L.). Skripsi. Fakultas Pertanian Unsyiah. Darussalam, Banda Aceh.

Gomez. K A dan A.A. Gomez. 1995. Prosedur Statistika untuk Penelitian Pertanian. UI Press, Jakarta.

Kramadibrata, M.A.M, 2000. Analisis Kinerja Beberapa Struktur Geometrik Bajak Singkal pada Pengolahan Lahan Sawah. Disertasi. Institut Pertanian Bogor, Bogor.

Mardinata, Z dan Zulkifli. 2014. Analisis Kapasitas Kerja dan Kebutuhan Bahan Bakar Traktor Tangan Berdasarkan Variasi Pola Pengolahan Tanah, Kedalaman Pembajakan dan Kecepatan Kerja. Jurnal Agritech, Vol 34, No. 3, Agustus 2014. Universitas Islam Riau, Pekanbaru.

Wahyuni, F. 2014. Pengaruh Kedalaman Pengolahan Tanah dengan Menggunakan Bajak Piring dan Pemupukan Phosphate Terhadap Pertumbuhan serta Produksi Tanaman Kedelai (Glycine max (L.) MERRIL). Skripsi. Fakultas Pertanian Unsyiah. Darussalam, Banda Aceh.

Yunus, Y. 2004. Tanah dan Pengolahan. Penerbit Alfabeta, Bandung.

. 2013. Dinamika Mesin dan Tanah dalam Pengoperasian Traktor. Penerbit Alfabeta, Bandung. 